\title{
Analysis of transcription and translation of glycolytic enzymes in glucose-limited continuous cultures of Saccharomyces cerevisiae
}

\author{
Laurens N. Sierkstra, ${ }^{1}$ John M. A. Verbakel ${ }^{2}$ and C. Theo Verrips ${ }^{2}$ \\ ${ }^{1}$ Department of Molecular Cell Biology, University of Utrecht, Padualaan 8, $3584 \mathrm{CH}$ Utrecht, The Netherlands \\ ${ }^{2}$ Unilever Research Laboratorium, Olivier van Noortlaan 120, 3133 AT Vlaardingen, The Netherlands
}

(Received 16 October 1991; revised 6 July 1992; accepted 20 August 1992)

\begin{abstract}
mRNA steady-state levels and activities of enzymes of intermediary carbon metabolism (hexokinase, phosphoglucoisomerase, phosphofructokinase, glucose-6-phosphate dehydrogenase, phosphoglucomutase) and glucose-regulated enzymes (pyruvate decarboxylase, pyruvate dehydrogenase, invertase, alcohol dehydrogenase) were determined in glucose-limited continuous cultures of an industrial strain of Saccharomyces cerevisiae at different dilution rates $(D)$ ranging from 0.05 to $0.315 \mathrm{~h}^{-1}$. The activity of most enzymes measured remained constant over this range except for alcohol dehydrogenase $\mathrm{I} / \mathrm{II}$ which decreased proportionally with increasing dilution rate. A decrease in phosphoglucomutase activity occurred with increasing dilution rate but reached a minimum at $D 0.2 \mathrm{~h}^{-1}$ and from thereon remained constant. A decrease in pyruvate decarboxylase activity and a slight decrease in phosphoglucoisomerase activity was observed. At $D 0 \cdot 29 / 0 \cdot 315 \mathrm{~h}^{-1}$, at the onset of the Crabtree effect, most glycolytic enzymes remained constant except for pyruvate decarboxylase and glucose-6-phosphate dehydrogenase which increased at $D 0.315 \mathrm{~h}^{-1}$ and alcohol dehydrogenase I/II which decreased. The $A D H I / I I$ and $P D C 1$ mRNA levels obtained at the different dilution rates were in accordance with the activity measurements. The mRNA level of $H X K 1$ decreased with increasing dilution rates, whereas the transcription of $H X K 2$ increased. Pyruvate dehydrogenase (PDA1) and PGII mRNA fluctuated but no significant change could be detected. These results indicate that there is no transcriptional or translational regulation of glycolytic flux between $D 0.05 \mathrm{~h}^{-1}$ and $0.315 \mathrm{~h}^{-1}$ except at the branch point between oxidative and fermentative metabolism (pyruvate decarboxylase/ pyruvate dehydrogenase) at $D \mathbf{0 . 3 1 5} \mathrm{h}^{-1}$. Surprisingly regulation of the Crabtree effect does not seem to involve transcriptional regulation of $P D A 1$. The concentrations of ATP and cAMP decreased slightly during the increase in dilution rate, but increased again at $D \mathrm{0} \cdot 315 \mathrm{~h}^{-1}$. The concentrations of glucose 6-phosphate and fructose 6-phosphate did not increase when the dilution rate increased as expected from the activities of hexokinase, phosphoglucoisomerase and phosphofructokinase. Instead, a decrease in the glucose 6-phosphate and fructose 6-phosphate concentrations was observed. The concentration of glucose 1-phosphate also decreased with increasing dilution rate but increased again at $D 0.29$ and $0.315 \mathrm{~h}^{-1}$, whereas the fructose 1,6-diphosphate concentration increased from $0.05 \mathrm{~h}^{-1}$ to $0 \cdot 315 \mathrm{~h}^{-1}$. These data indicate that glycolytic flux in $S$. cerevisiae is regulated mainly by allosteric regulation of glycolysis when growth rate is increased. Invertase was present (mRNA and activity) at every dilution rate which indicates that glucose-specific repression of enzyme systems is not present in glucose-limited continuous cultures, not even when the yeast produces ethanol. This also indicates that the Crabtree effect is not related to glucose repression.
\end{abstract}

\section{Introduction}

When Saccharomyces cerevisiae is grown on glucose the synthesis of many enzymes is repressed at the transcriptional level. The enzymes whose synthesis is repressed

Correspondence to: J. F. Deij, Management Support \& Communication, Unilever Research Laboratorium, P.O. Box 114, 3130 AC Vlaardingen, The Netherlands. Tel. 10 4605804; fax 104605637. include enzymes involved in the use of carbon sources other than glucose, e.g. invertase, alcohol dehydrogenase, and the enzymes of the Leloir pathway. Gluconeogenic (fructose-1,6-biphosphatase) and TCA cycle (malate dehydrogenase) enzymes are also repressed. This phenomenon is known as carbon catabolite repression (Gancedo \& Gancedo, 1986; Entian, 1986). Catabolite inactivation or activation is the term assigned to the rapid loss or rise of activity of the enzymes fructose- 
1,6-bisphosphatase (Gancedo \& Gancedo, 1971) and trehalase, respectively (van der Plaat, 1974; Ortiz et al., 1983; Uno et al., 1983) upon addition of glucose to cells growing on non-fermentable carbon sources such as glycerol. This not only causes changes at the transcriptional level which results in long-term repression of enzyme synthesis, but also causes momentary decreases or increases in activity of certain enzymes. It is not known if the effects of glucose are mediated via one signal transduction pathway or whether more than one pathway is involved.

Most probably the RAS/cAMP pathway (Broach, 1991) is also involved in glucose signalling. Upon addition of glucose a transient increase in cAMP is observed, which seems to coincide with phosphorylation of the transcriptional activator ADRI (Cherry et al., 1989) and phosphorylation of proteins (e.g. fructose1,6-biphosphatase; Rittenhouse et al., 1987) at the cAMP-dependent phosphorylation site. However, the RAS/cAMP pathway is a signal transduction pathway for general responses, because mutants in this pathway show pleiotropic phenotypes (e.g. Toda et al., 1987). The exact signal which activates the RAS/cAMP pathway is not known but Beullens et al. (1988) found evidence that the metabolism of glucose beyond glucose 6-phosphate is not necessary for the increase in cAMP.

Most data on the mechanism of glucose repression come from experiments using mutants with pleiotropic phenotypes under non-defined physiological conditions in shake-flask batch cultures. Continuous cultures offer an excellent tool to study glucose repression under defined physiological conditions (Fiechter et al., 1981) because the growth rate of the organism can be regulated, allowing reproducible sampling of cells. At low growth rates [for strain SU32 a dilution rate $(D)$ $<0.275 \mathrm{~h}^{-1}$ ] in glucose-limited continuous cultures all glucose is consumed oxidatively resulting in a respiratory quotient $\left(\mathrm{RQ}=\mathrm{rCO}_{2} / \mathrm{qO}_{2}\right)$ of 1.04 . In this case the residual glucose concentration is approximately $0.1 \mathrm{mM}$ (Postma et al., 1989b; this study). However, at higher dilution rates (for SU32 $>0.275 \mathrm{~h}^{-1}$ ) an increase in RQ and residual glucose concentration as well as ethanol production is observed. This ethanol production in the presence of oxygen and in the absence of an excess of glucose is known as the Crabtree effect (Crabtree, 1929). The occurrence of the Crabtree effect is often linked to glucose repression (Dunlop \& Ye, 1990; Postma et al., $1989 a$ ). The dilution rate at which ethanol is produced seems to be strain-dependent (von Meyenburg, 1969; Postma et al., 1989a; Rieger et al., 1983; this study).

To investigate glucose repression by means of continuous culture it is essential first to describe precisely the exact physiological state of the yeast. Important parameters are mRNA levels and activities of glycolytic enzymes (from hexokinase to aldolase), of glucoseregulated enzymes (invertase, alcohol dehydrogenase II, pyruvate decarboxylase) and of enzymes at the branch point of fermentative and oxidative metabolism (pyruvate decarboxylase and pyruvate dehydrogenase), and the concentrations of glycolytic intermediates of the first part of glycolysis (glucose 6-phosphate to fructose 1,6-bisphosphate), ATP and cAMP. This study was carried out first to investigate if there is glucose-specific repression of enzymes (e.g. alcohol dehydrogenase II; Postma et al., 1989a) at higher dilution rates and to analyse if glucose repression is indeed related to aerobic ethanol production (e.g. Dunlop \& Ye, 1990). Second, it is important to examine the regulation of glycolytic flux because the signal transmitting glucose repression may depend upon high concentrations of extra- or intracellular glucose or of a glucose metabolite.

\section{Methods}

Strain and growth conditions. Commercial bakers' yeast strain SU32 was grown in medium containing $\left(\mathrm{g} \mathrm{l}^{-1}\right) \mathrm{NH}_{4} \mathrm{Cl}(7 \cdot 63), \mathrm{KH}_{2} \mathrm{PO}_{4}(2 \cdot 81)$, $\mathrm{MgSO}_{4} .7 \mathrm{H}_{2} \mathrm{O}(0.59), 10 \mathrm{ml}$ trace elements $\mathrm{l}^{-1}$ [a $100 \times$ concentrate containing $\left(\mathrm{g} \mathrm{I}^{-1}\right) \quad \mathrm{CaCl}_{2} \cdot 2 \mathrm{H}_{2} \mathrm{O} \quad(5 \cdot 5), \quad \mathrm{FeSO}_{4} \cdot 7 \mathrm{H}_{2} \mathrm{O}$ (3.75), $\mathrm{MnSO}_{4} \cdot \mathrm{H}_{2} \mathrm{O}(1 \cdot 4), \mathrm{ZnSO}_{4} \cdot 7 \mathrm{H}_{2} \mathrm{O}(2 \cdot 2), \mathrm{CuSO}_{4} \cdot 5 \mathrm{H}_{2} \mathrm{O}(0 \cdot 4)$, $\mathrm{CoCl}_{2} \cdot 6 \mathrm{H}_{2} \mathrm{O}(0.45), \mathrm{Na}_{2} \mathrm{MoO}_{4} .2 \mathrm{H}_{2} \mathrm{O}(0.26), \mathrm{H}_{3} \mathrm{Bo}_{3}(0.4)$, KI $(0.26)$ and $\mathrm{Na}_{2}$ EDTA (30)] and $1.5 \mathrm{ml}$ vitamin solution $\mathrm{I}^{-1}$ [a $1000 \times$ concentrate containing $\left(\mathrm{g} \mathrm{l}^{-1}\right)$ biotin $(0.05)$, thiamin (5), myoinositol (47), pyridoxin (1.2) and pantothenic acid (23)] per glucose (20) in the feed. $S$. cerevisiae SU32 was grown at $30^{\circ} \mathrm{C}$ under glucose limitation, with 10 or $30 \mathrm{~g}$ glucose $\mathrm{I}^{-1}$ in the feed, in a fermenter with a 21 working volume connected to an Applikon ADI1020 controller unit. All results shown are from the experiments with $10 \mathrm{~g}$ glucose $\mathrm{l}^{-1}$ in the continuous feed. The $\mathrm{pH}$ was automatically maintained at 5.0 by the addition of $2 \mathrm{M}-\mathrm{NH}_{4} \mathrm{OH}$. The air flow rate was $21 \mathrm{~min}^{-1}$ and the dissolved oxygen tension was kept above $20 \%$ by regulating the stirrer speed. $\mathrm{CO}_{2}$ production $\left[\mathrm{rCO}_{2}\right.$ in $\mathrm{mmol} \mathrm{h}^{-1}$ per gram dry weight (g)], oxygen consumption $\left(\mathrm{qO}_{2}\right.$ in $\left.\mathrm{mmol} \mathrm{h}^{-1} \mathrm{~g}^{-1}\right)$ and ethanol formation were measured continuously on line by connecting the fermenter head-space to a VG MM8-80 gas analysis mass spectrometer.

Preparation of samples. Samples were taken in duplicate every day for three successive days only when a steady-state had been reached.

For the preparation of cell free extracts, used in enzyme assays, $1.5 \mathrm{ml}$ culture liquid was transferred from the fermenter to an Eppendorf tube and put on ice. The cells were pelleted for $30 \mathrm{~s}$ by centrifugation and resuspended in $1 \mathrm{ml} 10 \mathrm{~mm}$-potassium phosphate buffer ( $\mathrm{pH} 7.5$ ) containing $2 \mathrm{mm-EDTA}$. The cells were again pelleted and resuspended in $1 \mathrm{ml} 100 \mathrm{~mm}$-potassium phosphate buffer ( $\mathrm{pH} 7.5)$ containing $2 \mathrm{mM}-\mathrm{MgCl}_{2}$ and $2 \mathrm{~mm}$-dithiothreitol. Cell-free extracts were prepared by adding an equal volume of glass beads and the cells were lysed by shaking the suspension four times at maximum speed on a vortex mixer for $30 \mathrm{~s}$ with $1 \mathrm{~min}$ intervals on ice. Lysed cells were separated from the glass beads after which the suspension was centrifuged to remove cell debris. The clear supernatant was frozen quickly in liquid nitrogen and kept at $-80^{\circ} \mathrm{C}$ until it was used for enzyme assays. The protein concentration of cell-free extracts was determined by the method of Bradford (1976) with the Bio-Rad dyereagent using bovine serum albumin (Sigma) as a standard. Protein concentrations were always between $1-6 \mathrm{mg}(\mathrm{ml} \text { extract })^{-1}$. 
Table 1. Oligonucleotides used in this study

\begin{tabular}{|c|c|}
\hline $\begin{array}{c}\text { mRNA } \\
\text { detected }\end{array}$ & Oligonucleotide sequence \\
\hline$H X K I$ & $5^{\prime}$ TAAGGTGTCCTTGGTGTTTAGCAATTC $3^{\prime}$ \\
\hline$H X K 2$ & 5' AATTGGCTCAGAGATACCTTGTGGGAA $3^{\prime}$ \\
\hline$P G I I$ & $5^{\prime}$ ACTTCGGTTTCGTTAGTGGACAAAGCAGCG $3^{\prime}$ \\
\hline$A D H I / I I$ & 5' CGTTACCCAATTGACAGTATTCACAGGCCA 3' \\
\hline$P D A I$ & 5' CACTGTGTCCGAGCCCTCGATGTCCTC $3^{\prime}$ \\
\hline$P D C l$ & $5^{\prime}$ AGACATTCTGTGGAAAACAGTGAAGTCACC $3^{\prime}$ \\
\hline$S U C 2$ & $5^{\prime}$ TGGGTCAGTGTTGAAGAAAGTTTGCAAGGC $3^{\prime}$ \\
\hline$A C T I$ & $5^{\prime}$ TGTCTTGGTCTACCGACGATAGATGGGAAG $3^{\prime}$ \\
\hline$H 2 A / H 2 B$ & 5' GACTGGAGCACCAGAACCAATTCTTTGGGC 3' \\
\hline
\end{tabular}

mRNA extraction was as described by Sierkstra et al. (1991).

Samples for determination of glycolytic intermediates ATP and cAMP were taken by transferring $3 \mathrm{ml}$ of culture liquid from the fermenter to a tube in liquid nitrogen (within $10 \mathrm{~s}$ ). These were stored at $-80^{\circ} \mathrm{C}$. The frozen culture liquid was heated quickly to $80^{\circ} \mathrm{C}$ in boiling ethanol for $1 \mathrm{~min}$ to inactivate enzymes as quickly as possible. This liquid mixture was removed by vacuum drying. The resulting pellet was dissolved in $1 \mathrm{ml}$ of $\mathrm{H}_{2} \mathrm{O}$ and stored at $-80^{\circ} \mathrm{C}$ until assayed. All enzymes were inactivated by this extraction procedure.

Sampling of culture liquid for the determination of extracellular metabolites (acetate, acetaldehyde, glycerol, pyruvate, ethanol and the residual glucose concentration) was performed as described by Postma et al. (1988). However, this method overestimates the extracellular concentrations of metabolites because lysis occurs due to freezing of the cells.

For the determination of dry weight $20 \mathrm{ml}$ culture was collected from the fermenter's outlet. The cells were pelleted, washed with distilled water and transferred to pre-weighed glass vials in which they were dried overnight at $120^{\circ} \mathrm{C}$.

Measurement of metabolites, ATP and cAMP. Glycolytic intermediates were measured enzymically as described by Bergmeyer (1974). ATP was assayed by measuring glucose consumption by hexokinase. Extracellular metabolites (ethanol, acetate, acetaldehyde, pyruvate and glycerol) were determined enzymically or by HPLC. Total cAMP was determined with the Amersham cAMP-kit based on competition between labelled and unlabelled CAMP with a cAMPbinding protein.

Enzyme assays. Enzyme activities were measured at maximal velocity as described by Bergmeyer (1974) in $50 \mathrm{~mm}$-imidazole/ $\mathrm{HCl}$ buffer ( $\mathrm{pH} 7.0$ ) containing $5 \mathrm{~mm}-\mathrm{MgCl}_{2}$. Reaction velocities were proportional to the amount of enzyme added. Activities are in $U(\mathrm{mg}$ total cellular soluble protein $)^{-1}$ in which $1 \mathrm{U}$ is defined as the conversion of $1 \mu \mathrm{mol}$ of substrate $\mathrm{min}^{-1}$ at $30^{\circ} \mathrm{C}$ at $\mathrm{pH} 7 \cdot 0$. All enzyme assays were performed on the Cobas Mira autoanalyser of Hoffmann Laroche.

Labelling of oligonucleotides. For Northern analysis the oligonucleotides listed in Table 1 were used. $H X K 1, H X K 2, P G I 1, A D H I / I I, P D A 1$, $P D C 1, S U C 2, A C T 1$ and $H 2 A / H 2 B$ are the structural genes for hexokinase isoenzyme 1 and 2 , phosphoglucoisomerase, alcohol dehydrogenase I and II, pyruvate dehydrogenase (El $\alpha$-subunit), pyruvate decarboxylase, invertase, actin and histones $2 \mathrm{~A}$ and $2 \mathrm{~B}$, respectively. Oligonucleotides were labelled by incubating $25 \mathrm{pmol}$ of oligonucleotide with 1 unit of T4 polynucleotide kinase and $1.85 \mathrm{MBq}$ [32P]ATP.

Northern blot analysis. RNA samples (containing $3 \mu \mathrm{g}$ total RNA) were separated on a denaturating formamide/formaldehyde gel. RNA

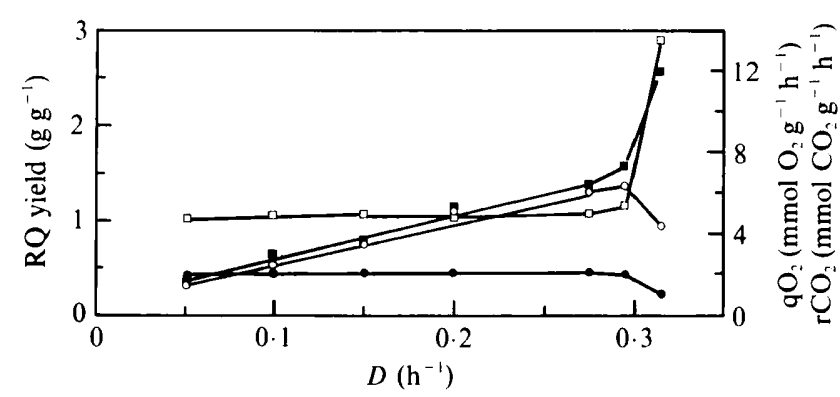

Fig. 1. The specific oxygen consumption $\left(\mathrm{qO}_{2} ; \mathrm{O}\right), \mathrm{CO}_{2}$ production $\left(\mathrm{rCO}_{2} ; \square\right), \mathrm{RQ}(\square)$ and yield $(\bullet)$ as a function of the dilution rate of $S$. cerevisiae $\mathrm{SU} 32$. $\mathrm{RQ}$ is defined as the quotient of the $\mathrm{CO}_{2}$ produced $\left(\mathrm{mmol} \mathrm{g}^{-1} \mathrm{~h}^{-1}\right)$ and the $\mathrm{O}_{2}$ consumed $\left(\mathrm{mmol} \mathrm{g}^{-1} \mathrm{~h}^{-1}\right)$. The yield is defined as the amount of biomass $(\mathrm{g})$ per gram carbon source.

was blotted onto Hybond paper using the vacugene system of Pharmacia or by capillary blotting. The RNA was crosslinked to Hybond by exposure to UV light. Blots were prehybridized at least $2 \mathrm{~h}$

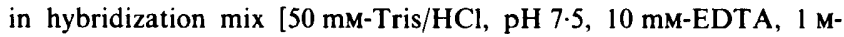
$\mathrm{NaCl}, 0 \cdot 1 \% \mathrm{SDS}, 0 \cdot 1 \%$ sodium pyrophosphate, $0.2 \%$ Ficoll, $0.2 \% \mathrm{BSA}$,

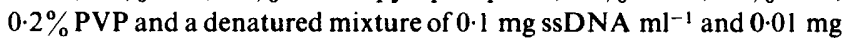
poly(rA) $\mathrm{ml}^{-1}$ ] at $42^{\circ} \mathrm{C}$. Hybridization was performed overnight at $42^{\circ} \mathrm{C}$ in hybridization mix with the denatured oligonucleotide $(5 \mathrm{~min}$, $100^{\circ} \mathrm{C}$ ). The filters were washed once for $20 \mathrm{~min}$ with $5 \times \mathrm{SSC}$, once in $2 \times \mathrm{SSC}$ and twice in $1 \times \mathrm{SSC}$, all at $42^{\circ} \mathrm{C}$. Thereafter the filters were exposed to X-ray film. Histone or actin mRNAs were used as internal controls. The amount of specific mRNA was measured on a LKB Ultroscan XL densitometer. Different exposure times were used in order to obtain reliable scanning data.

Biochemicals. All enzymes, ATP, NADP, NAD, NADH and metabolites were purchased from Boehringer, except glycerol3-phosphate dehydrogenase, triose-phosphate isomerase and fructose2,6-bisphosphate which were purchased from Sigma.

\section{Results}

\section{Physiological parameters}

S. cerevisiae strain SU32 was grown under glucose limitation at different dilution rates in a chemostat. The specific oxygen uptake and carbon dioxide production increased linearly with increasing dilution rate up to $0 \cdot 275 \mathrm{~h}^{-1}$ (Fig. 1). The residual glucose concentration at this dilution rate was $0 \cdot 1 \mathrm{mmol} \mathrm{l}^{-1}$. At the onset of the Crabtree effect between 0.275 and $0.29 \mathrm{~h}^{-1}$, the maximal specific oxygen uptake of SU32 was observed $(6.5 \mathrm{mmol}$ $\left.\mathrm{O}_{2} \mathrm{~g}^{-1} \mathrm{~h}^{-1}\right)$. At $D 0.29 \mathrm{~h}^{-1}, 0.3 \mathrm{~g}$ ethanol $\mathrm{l}^{-1}, 0.14 \mathrm{~g}$ acetate $\mathrm{l}^{-1}$ and $0.01 \mathrm{~g}$ pyruvate $\mathrm{l}^{-1}$ was observed in the medium. This secretion of metabolites resulted in a decrease in growth yield from 0.45 to 0.42 [g biomass (g glucose) $^{-1}$ ]. An increase in RQ to $1 \cdot 15$ was observed at this dilution rate. A further increase in dilution rate to $0 \cdot 315 \mathrm{~h}^{-1}$ resulted in a decrease of the specific oxygen uptake to $4.4 \mathrm{mmol} \mathrm{O}_{2} \mathrm{~g}^{-1} \mathrm{~h}^{-1}$ and an increase in $\mathrm{CO}_{2}$ production from 7.3 to $12.0 \mathrm{mmol} \mathrm{CO}_{2} \mathrm{~g}^{-1} \mathrm{~h}^{-1}$, and 


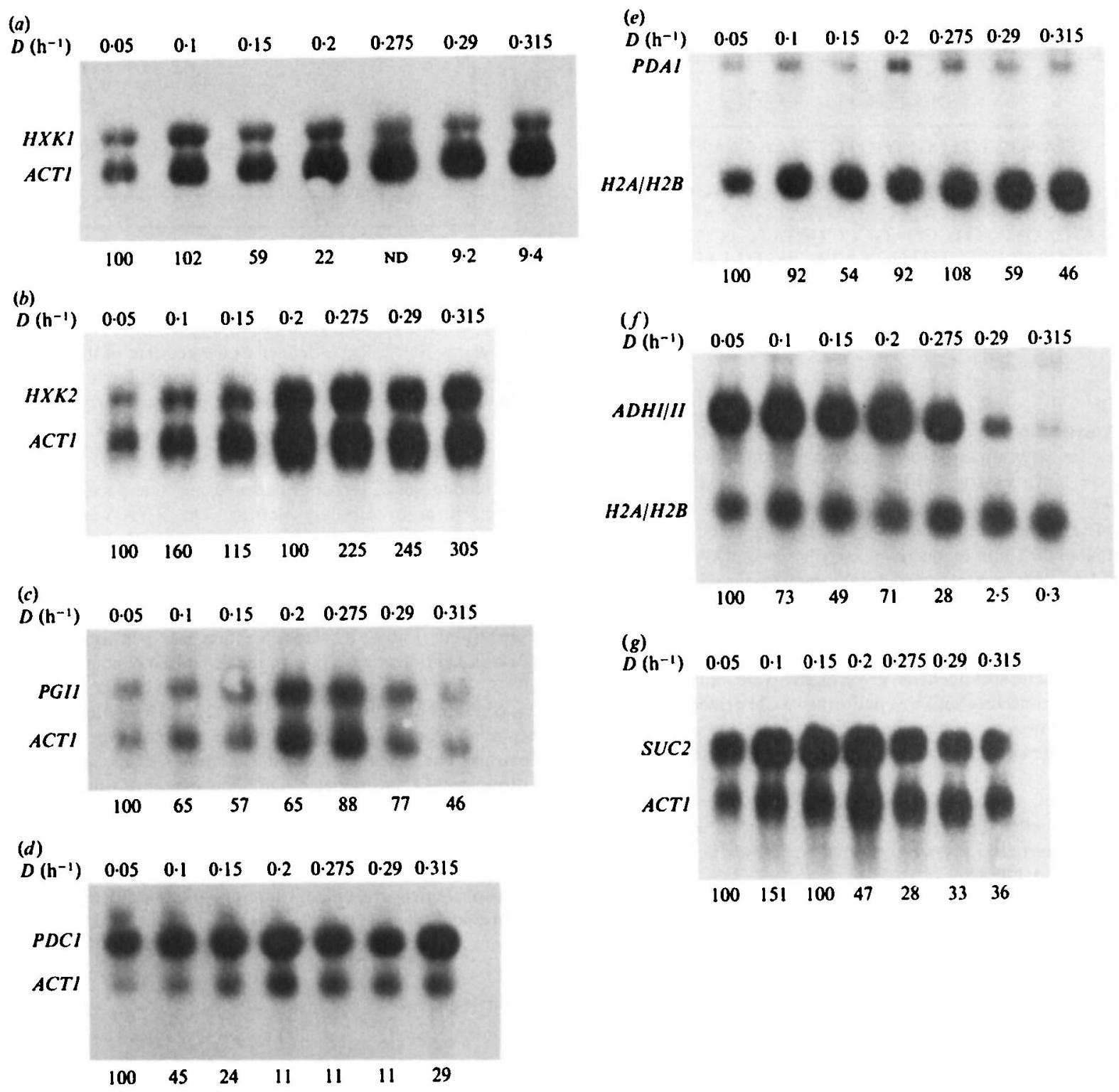

Fig. 2. Northern blots of mRNA isolated at different dilution rates from 0.05 to $0.315 \mathrm{~h}^{-1}$ are shown. The Northern blots were hybridized with probes specific to the mRNA of $(a) H X K 1,(b) H X K 2,(c) P G I,(g) S U C 2$ and $(d) P D C 1$ with actin as an internal control. Blots $(e)$ and $(f)$ were hybridized with probes specific to the mRNA of $(e) P D A I$ and $(f) A D H I / I I$ with histone as internal control. The blots were quantified by densitometry. The specific amount of mRNA (as corrected for the total amount of RNA on the gel by the scanned value for the internal control, histone or actin) is shown beneath each lane. The amount of specific $\mathrm{mRNA}^{2} D 0.05 \mathrm{~h}^{-1}$ is taken as the $100 \%$ value. ND, Not determined.

consequently in an increase in $\mathrm{RQ}$ to $2 \cdot 8$. As a result of this shift to fermentative metabolism ethanol production by the yeast increased to $2 \cdot 3 \mathrm{~g}^{-1}$. Also, $0 \cdot 11 \mathrm{~g}$ acetate $1^{-1}, 0 \cdot 25 \mathrm{~g}$ acetaldehyde $1^{-1}$ and $0.02 \mathrm{~g}$ pyruvate $\mathrm{l}^{-1}$ were observed in the culture liquid. The residual glucose concentration increased to $0.27 \mathrm{mmol} \mathrm{1}^{-1}$.

$S$. cerevisiae SU32 produced a constant amount of $9 \mathrm{mg}$ glycerol $\mathrm{g}^{-1}$ at low dilution rates $\left(<0.275 \mathrm{~h}^{-1}\right)$. This increased to $50 \mathrm{mg} \mathrm{g}^{-1}$ when the yeast produced ethanol
(D $0.315 \mathrm{~h}^{-1}$ ) as observed by others (Postma et al., $1989 a$ ). The experiments were also carried out with a glucose concentration of $30 \mathrm{~g}^{-1}$ in the feed: no differences were observed in the physiological parameters (results not shown).

\section{$m R N A$ levels at increasing dilution rates}

To investigate transcriptional regulation of $H X K 1$, $H X K 2, P G I 1, P D C l, P D A 1, A D H I / I I$ and SUC2, 
mRNAs were isolated at different dilution rates and Northern analysis was performed. Due to extensive sequence identity between the two ADH genes no oligonucleotide could be designed which could discriminate between the two different mRNAs. Therefore, the signal on the Northern blots comes from both mRNAs. This is also the case for both histone genes $\mathrm{H} 2 \mathrm{~A}$ and H2B.

The transcription of $H X K l$ (panel A) was constant at $D 0.05$ and $0.1 \mathrm{~h}^{-1}$, but then decreased with increasing dilution rate to about $10 \%$ of the initial value at $0.29 \mathrm{~h}^{-1}$ (Fig. 2a). The $H X K 2$ mRNA (Fig. $2 b$ ) increased slightly at $0 \cdot 1 \mathrm{~h}^{-1}$ and then decreased again to the initial value at $0 \cdot 2 \mathrm{~h}^{-1}$. From 0.2 to $0.315 \mathrm{~h}^{-1}$, a threefold increase in the $H X K 2$ mRNA could be seen. Transcription of PGII (Fig. $2 c$ ) fluctuated between 88 and $46 \%$ of the initial value at $D 0.05 \mathrm{~h}^{-1}$.

$P D C 1$ mRNA decreased with increasing dilution rate but remained constant at $D 0.2 \mathrm{~h}^{-1}$ and higher; however, at $0.315 \mathrm{~h}^{-1}$ an induction of the $P D C 1 \mathrm{mRNA}$ occurred (Fig. $2 d$ ). The amount of specific PDAl mRNA fluctuated between 108 and $46 \%$ of the initial value (Fig. $2 e$ ).

A decrease in the mRNA level of $A D H I / I I$ occurred with increasing dilution rate (Fig. $2 f$ ); at $0.315 \mathrm{~h}^{-1}$ the mRNA amount was only $0.3 \%$ of the initial value at $0.05 \mathrm{~h}^{-1} . S U C 2 \mathrm{mRNA}$ was present at all dilution rates, even when the yeast produced ethanol (Fig. $2 g$ ) but the highest level of $S U C 2$ mRNA was observed at low dilution rates.

\section{Enzyme levels at increasing dilution rates}

Increasing the dilution rate of $S$. cerevisiae in a glucoselimited continuous culture leads to an increase in glycolytic flux, e.g. from 0.1 to $0.2 \mathrm{~h}^{-1}$ the sugar consumption $\mathrm{g}^{-1}$ increases twofold. To determine whether $S$. cerevisiae responds to this increase in glycolytic flux by changing the amount of its glycolytic enzymes, total soluble protein was isolated at each dilution rate and the activity of different enzymes was measured in this crude extract.

From $D 0.05$ to $0.315 \mathrm{~h}^{-1}$ the activity of hexokinase remained constant at about $2 \mathrm{U}$ (mg protein $)^{-1}$, whereas the activity of phosphoglucoisomerase decreased slightly. The activity of phosphoglucomutase decreased from $1.2 \mathrm{U}$ (mg protein) $)^{-1}$ at $0.05 \mathrm{~h}^{-1}$ to $0.37 \mathrm{U}$ (mg protein $)^{-1}$ at $0.275 \mathrm{~h}^{-1}$ and remained constant at 0.29 and $0.315 \mathrm{~h}^{-1}$ (Fig. $3 a$ ).

The activity of glucose-6-phosphate dehydrogenase remained constant during the increase in dilution rate at about $0.25 \mathrm{U}$ (mg protein $)^{-1}$ but an increase in activity to $0.45 \mathrm{U}$ (mg protein $)^{-1}$ was observed at $0.315 \mathrm{~h}^{-1}$. A slight decrease in phosphofructokinase activity was observed.
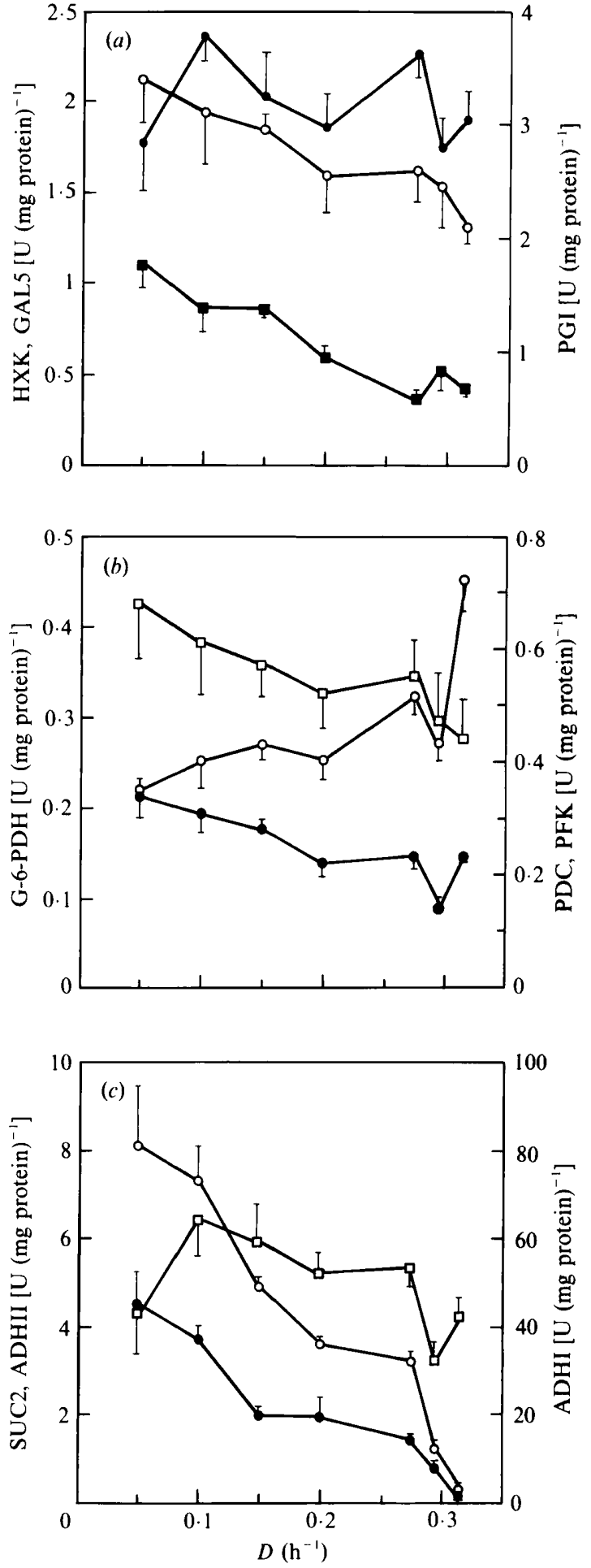

Fig. 3. Specific activities of the following enzymes as a function of the dilution rate: (a) HXK (hexokinase: •), PGI (phosphoglucoisomerase : O) and GAL5 (phosphoglucomutase: $\square$ ); (b) G-6-PDH (glucose6-phosphate dehydrogenase: $O$ ), PFK (phosphofructokinase: $\square$ ) and PDC (pyruvate decarboxylase: ๑); (c) SUC2 (invertase: $\square$ ), ADHI (alcohol dehydrogenase I: $\bullet$ ) and ADHII (alcohol dehydrogenase II O). Results shown are the means of three independently isolated samples assayed in duplicate. 
Table 2. The concentration of glucose 6-phosphate (G-6-p), fructose 6-phosphate (F-6-p), glucose 1-phosphate (G-1-p), fructose 1,6-bisphosphate (F-1,6-bp) and ATP $\left(\mu \mathrm{mol} \mathrm{g}{ }^{-1}\right)$ as a function of the dilution rate $(D)$

The concentration of cAMP (intra- and extracellular) as a function of the dilution rate is given in $\mathrm{nmol}^{-1}$. The values represent determinations of at least four independent isolations. ND, Not determined.

\begin{tabular}{lllllll}
\hline \hline$D\left(\mathrm{~h}^{-1}\right)$ & G-6-p & F-6-p & G-1-p & F-1,6-bp & ATP & cAMP \\
\hline 0.05 & $1.92 \pm 0.02$ & $0.29 \pm 0.1$ & $7.3 \pm 1.2$ & $1.3 \pm 0.22$ & $5.4 \pm 0.8$ & $9.3 \pm 1.5$ \\
0.1 & $0.98 \pm 0.23$ & $0.2 \pm 0.09$ & $5.0 \pm 0.5$ & $1.6 \pm 0.2$ & $5.3 \pm 0.7$ & $7.4 \pm 1.3$ \\
0.15 & $1.22 \pm 0.3$ & $0.2 \pm 0.05$ & $2.9 \pm 0.7$ & $2.8 \pm 0.4$ & $4.9 \pm 0.8$ & $5.4 \pm 0.9$ \\
0.2 & $0.63 \pm 0.1$ & $0.06 \pm 0.02$ & $0.6 \pm 0.02$ & $3.2 \pm 0.5$ & $4.2 \pm 0.5$ & $6.0 \pm 1.6$ \\
0.275 & $0.56 \pm 0.14$ & $0.04 \pm 0.01$ & $0.38 \pm 0.05$ & ND & $4.3 \pm 0.1$ & $5.7 \pm 0.1$ \\
0.29 & $0.24 \pm 0.02$ & $0.02 \pm 0.01$ & $0.63 \pm 0.05$ & ND & $3.2 \pm 0.6$ & $3.5 \pm 0.1$ \\
0.315 & $1.6 \pm 0.4$ & $0.18 \pm 0.01$ & $1.1 \pm 0.15$ & $6.3 \pm 1.1$ & $5.5 \pm 0.6$ & $6.0 \pm 2.1$ \\
\hline \hline
\end{tabular}

Pyruvate decarboxylase activity decreased during the increase in dilution rate but increased again at $0.315 \mathrm{~h}^{-1}$ (Fig. $3 b$ ).

The activity of alcohol dehydrogenase I (acetaldehyde as substrate) and alcohol dehydrogenase II (ethanol as substrate) decreased from 45 and $8.1 \mathrm{U}$ (mg protein) ${ }^{-1}$, respectively, at $D 0.05 \mathrm{~h}^{-1}$ to 1.2 and $0.29 \mathrm{U}(\mathrm{mg}$ protein) $)^{-1}$, respectively, at $D 0.315 \mathrm{~h}^{-1}$ (Fig. $3 c$ ). Invertase activity was present at every dilution rate, even when the yeast produced ethanol [maximum activity $6 \mathrm{U}$ (mg protein) $)^{-1}$ at $D 0 \cdot 1 \mathrm{~h}^{-1} / 0 \cdot 15 \mathrm{~h}^{-1}$; minimum activity $4.2 \mathrm{U}$ (mg protein) $)^{-1}$ at $D 0.05 \mathrm{~h}^{-1} / 0.315 \mathrm{~h}^{-1}$ ]. The yeast strain used is not constitutive for invertase expression (results not shown).

\section{Metabolite levels at increasing dilution rates}

Metabolite levels in continuous cultures are dependent on the influx of glucose and the in vivo $V_{\max }$ and $K_{\mathrm{m}}$ of the enzymes which convert the substrates into the metabolites measured and the concentration of the cofactors.

The glucose 6-phosphate and fructose 6-phosphate concentrations decreased considerably from $D 0.05$ to $0.29 \mathrm{~h}^{-1}$ from 1.92 and $0.29 \mu \mathrm{mol} \mathrm{g}^{-1}$ to 0.24 and $0.02 \mu \mathrm{mol} \mathrm{g}^{-1}$, respectively. However, at $D 0.315 \mathrm{~h}^{-1}$ an increase in the glucose 6-phosphate and fructose 6-phosphate concentrations up to 1.6 and $0.18 \mu \mathrm{mol} \mathrm{g}^{-1}$, respectively, occurred (Table 2). Glucose 1-phosphate decreased from $7.3 \mu \mathrm{mol} \mathrm{g}^{-1}$ at $D \quad 0.05 \mathrm{~h}^{-1}$ to $0.38 \mu \mathrm{mol} \mathrm{g}^{-1}$ at $D 0.275 \mathrm{~h}^{-1}$ and then increased again (to $\left.1 \cdot 1 \mu \mathrm{mol} \mathrm{g}^{-1}\right)$. The concentrations of ATP and cAMP decreased from $D 0.05$ to $0.29 \mathrm{~h}^{-1}$ but at $0.315 \mathrm{~h}^{-1}$ there was a rise in both the cAMP and ATP concentrations. The concentration of fructose 1,6-bisphosphate increased from $1.3 \mu \mathrm{mol} \mathrm{g}^{-1}$ at $D 0.05 \mathrm{~h}^{-1}$ to $6.3 \mu \mathrm{mol} \mathrm{g}^{-1}$ at $0.315 \mathrm{~h}^{-1}$ (Table 2).

Because of the fast sampling method used there was no separation of medium from cells, so the amount of cAMP given in Table 1 is the sum of intra- and extracellular cAMP. To investigate if there was any extracellular cAMP, as reported by Smith et al. (1990), culture liquid was quickly $(<10 \mathrm{~s})$ taken from the fermenter at $D$ $0.1 \mathrm{~h}^{-1}$ and the medium was separated from the cells by filtration through a $0.22 \mu \mathrm{m}$ Millipore filter. The filtrate was used in a cAMP assay and CAMP was indeed found in the medium (30 to $50 \%$ ). Additional experiments confirmed that this phenomenon is not restricted to continuous growth (results not shown).

\section{Discussion}

The addition of glucose to cells growing on nonrepressing carbon sources causes repression of gene transcription (e.g. ADHII; Cherry et al., 1989) and the phosphorylation of enzymes, e.g. fructose-1,6-bisphosphatase (Rittenhouse et al., 1987). These phosphorylation events seem to be cAMP-dependent and therefore it was proposed that the signal mediating this glucoseinduced phosphorylation is transferred by the RAS/ cAMP pathway. However, it is not known if all the effects of glucose are mediated by this pathway or whether other signal transduction pathways are involved. The exact signal which triggers these events is not known either, but the signal must be located in the first part of the glycolytic pathway as shown by Beullens et al. (1988).

No repression of enzyme systems was observed in glucose-limited continuous cultures (see below) which indicates that the presence of glucose and its glycolytic intermediates is not sufficient to cause glucose repression. This implicates that a threshold concentration of extra- or intracellular glucose or a glucose metabolite (e.g. glucose 6-phosphate) is responsible for the signal mediating glucose repression. To test this hypothesis it is essential to investigate regulation of glycolytic flux 
because the flux determines the concentrations of metabolites in vivo which could eventually lead to the signal for glucose excess.

In this study we investigated whether regulation of glycolytic flux occurs by measuring mRNA levels and enzyme activities in vitro at different dilution rates in continuous cultures. The analysis of the enzyme activity and mRNA level for phosphoglucoisomerase and the enzyme activity of phosphofructokinase determined at different dilution rates demonstrates that there is no clear correlation between the activity or mRNA level of these enzymes and the dilution rate, although the PGII mRNA fluctuated and a slight decrease in phosphoglucoisomerase activity was observed when the dilution rate increased. Total glucose-phosphorylating activity (glucokinase and hexokinase I and II) remained constant during the increase in dilution rate but a decrease in the amount of $H X K 1 \mathrm{mRNA}$ and a threefold increase in the $H X K 2$ transcript was observed at higher dilution rates. These results indicate that glycolytic flux is not regulated at either the transcriptional or translational levels. However, the in vivo activities of the measured enzymes could change with increasing dilution rate due to allosteric regulation, phosphorylation or the amount of cofactor(s) present. It is known, for example, that ATP is a very potent regulator of glycolytic flux and that at high concentrations it decreases the in vivo activity of hexokinase (Kopetzki \& Entian, 1985), phosphoglucoisomerase (Barman, 1969) and phosphofructokinase (Bar et al., 1990). The latter has been shown to be subject to a number of allosteric regulators, e.g. fructose 2,6-bisphosphate, $\mathrm{P}_{\mathrm{i}}$ and AMP (Reibstein et al., 1986).

Recent results from Schaaff et al. (1989) also indicate that glycolytic flux is strictly regulated. In order to increase the rate of fermentation they cloned the genes of glycolytic enzymes into a multi-copy vector and transformed the plasmids into yeast. Although increased amounts of enzyme were found, ethanol production was not increased and the levels of glycolytic intermediates were not reduced. Our data, which show decreased or constant amounts of glycolytic intermediates and constant enzyme activities during the increase in dilution rate, also strongly suggest that glycolytic flux is regulated through allosteric activation of the glycolytic enzymes. Studies are currently being carried out to investigate if glycolytic flux can be modelled with the data obtained by this study and additional data from the literature.

$S$. cerevisiae SU32, a commercial bakers' yeast strain, grown under glucose limitation reaches its maximum specific oxygen uptake of $6.5 \mathrm{mmol} \mathrm{O}_{2} \mathrm{~g}^{-1} \mathrm{~h}^{-1}$ between $D 0.275$ and $0.29 \mathrm{~h}^{-1}$. At this dilution rate the yeast starts producing ethanol. This aerobic production of ethanol by $S$. cerevisiae under conditions where there is no glucose excess is known as the long-term Crabtree effect, as opposed to the short-term Crabtree effect, which involves glucose excess (Van Urk, 1990). A further increase in dilution rate to $0.315 \mathrm{~h}^{-1}$ results in a decrease of the specific oxygen uptake to $4.4 \mathrm{mmol} \mathrm{O}_{2} \mathrm{~g}^{-1} \mathrm{~h}^{-1}$. Rieger et al. (1983) reported a constant specific oxygen uptake of the yeast during the Crabtree effect and they ascribed the decrease in specific oxygen consumption observed by von Meyenburg (1969) to a limitation in the feed. To exclude the possibility that a limitation in the feed was the cause of the decrease in specific oxygen uptake in our experiment, the experiment was performed with two different glucose concentrations (10 and $\left.30 \mathrm{~g} \mathrm{l}^{-1}\right)$. No differences in the physiological parameters were observed. In addition, Postma et al. (1989a) reported a slight decrease in specific oxygen uptake in the Crabtree effect. Therefore, it seems likely that the oxygen uptake at the onset of the Crabtree effect is strain-specific.

Our results indicate that not only at the onset of the Crabtree effect but also when the yeast produces ethanol there seems to be no transcriptional regulation of $P D A l$ (the El $\alpha$-subunit of the pyruvate dehydrogenase complex), although a fluctuation in the mRNA level between 108 and $46 \%$ of the initial value was observed at different dilution rates. In contrast, $P D C 1$ is regulated at the transcriptional level, as reported by Schmitt et al. (1983). At $D 0.315 \mathrm{~h}^{-1}$, when the yeast produces $2.3 \mathrm{~g}$ ethanol $1^{-1}$, an increase of the $P D C 1$ mRNA and activity was observed. However, this increase can not be due to an excess of glucose because the concentration of glucose was only $0.27 \mathrm{mmol} \mathrm{l}^{-1}$. This indicates that a mechanism of regulation, other than induction by glucose, is operative on $P D C l$ at the onset of the Crabtree effect. The transcriptional inducer of $P D C I$ could be one of the overflow metabolites at the branch point of the oxidative and the fermentative pathways (e.g. pyruvate, acetate, acetaldehyde or NADH). At the same dilution rate at which pyruvate decarboxylase increases, the activity of glucose-6-phosphate dehydrogenase also increases and the specific oxygen uptake decreases. Therefore, it seems likely that these changes are mediated by the overflow metabolism and are not specifically due to glucose.

When the dilution rate increased, $A D H I / I I \mathrm{mRNA}$ decreased and the activity of alcohol dehydrogenases I and II also decreased. It has been proposed that the decrease in activity of alcohol dehydrogenase II (but not of alcohol dehydrogenase I) and acetyl-CoA-synthethase is due to glucose repression of these enzymes at higher dilution rates in continuous cultures (Postma et al., $1989 a$ ). $A D H I I$ is known to be regulated by glucose via the transcriptional activator ADRI (Cherry et al., 1989). Invertase expression seems to be regulated only by glucose repression and derepression (Entian, 1986; Carlson, 1987), whereas regulation of $A D H I I$ is more 
complex (Denis, 1984). In contrast with the mRNA level and activity of alcohol dehydrogenase II, the mRNA level and activity of invertase hardly changed. Therefore, the decrease of alcohol dehydrogenase II cannot be glucose-specific or else the mechanism of glucose repression for invertase is different from the mechanism by which glucose controls the expression of $A D H I I$. A carbon-limited continuous culture with a non-repressing carbon source (galactose) is currently under investigation in our laboratory to distinguish between these two possibilities. The fact that invertase was present even when the yeast produced ethanol suggests there is no glucose-specific repression and that there is no link between glucose repression and the Crabtree effect in S. cerevisiae.

The authors appreciate the skilful assistance of $\mathbf{J}$. van Almkerk during fermentations and thank Drs M. L. F. Giuseppin, J. P. van Dijken and Professor Dr W. P. M. Hoekstra for valuable discussions.

\section{References}

Bar, J., Martinez-Costa, O. H. \& Aragon, J. J. (1990). Regulation of phosphofructokinase at physiological concentration of enzyme studied by stopped-flow measurements. Biochemical and Biophysical Research Communications 167, 1214-1220.

Barman, T. E. (1969). Enzyme Handbook, pp. 837-838. Berlin: Springer-Verlag.

BERGMEYER, H. U. (1974). Methods of Enzymatic Analysis. Weinheim: Verlag Chemie.

Beullens, M., Mbonyi, K., Geerts, L., Gladines, D., Detremerie, K., Jans, A. W. H. \& Thevelien, J. M. (1988). Studies on the mechanism of the glucose-induced cAMP signal in glycolysis- and glucose repression-mutants of the yeast $S$. cerevisiae. European Journal of Biochemistry 172, 227-231.

BRADFORD, M. M. (1976). A rapid and sensitive method for the quantitation of microgram quantities of protein utilizing the principle of protein-dye binding. Analytical Biochemistry 72, 248-254.

BROACH, J. R. (1991). RAS genes in Saccharomyces cerevisiae: signal transduction in search of a pathway. Trends in Genetics 7, 28-32.

CARLSON, M. (1987). Regulation of sugar utilization in Saccharomyces species. Journal of Bacteriology 169, 4873-4877.

Cherry, J. R., Johnson, T. R., Dollard, C., Shuster, J. R. \& Denis, C. L. (1989). cAMP dependent protein kinase phosphorylates and inactivates the yeast transcriptional activator ADR1. Cell 56, 409-419.

CrabtreE, H. G. (1929). Observations on the carbohydrate metabolism of tumors. Biochemical Journal 23, 536-545.

DENIS, C. L. (1984). Identification of new genes in the regulation of yeast alcohol dehydrogenase II. Genetics 108, 833-844.

DUNLOP, E. H. \& YE, S. J. (1990). Micromixing in fermentors: metabolic changes in Saccharomyces cerevisiae and their relationship to fluid turbulence. Biotechnology and Bioengineering 36, 854-864.

ENTIAN, K. D. (1986). Glucose repression : a complex regulatory system in yeast. Microbiological Sciences 3, 366-371.
Fiechter, A., FuhrmanN, G. F. \& Kappeli, O. (1981). Regulation of glucose metabolism in growing yeast cells. Advances in Microbial Physiology 22, 123-183.

GaNCEDO, J. M. \& GANCEDo, C. (1971). Fructose-1,6-diphosphatase, phosphofructokinase and glucose-6-phosphate dehydrogenase from fermenting and non-fermenting yeast. Archives of Microbiology 76, 132-138.

GaNCEDO, J. M. \& GANCEDO, C. (1986). Catabolite repression mutants of yeast. FEMS Microbiological Reviews 32, 179-187.

KopetzKI, E. \& ENTIAN, K. D. (1985). Glucose repression and hexokinase isoenzymes in yeast. European Journal of Biochemistry 146, 657-662.

voN MEYenburg, H. K. (1969). Katabolit Repression und der Sprossungszyklus von Saccharomyces cerevisiae. $\mathrm{PhD}$ thesis, Eidgenössische Technische Hochschule, Zürich, Switzerland.

Ortiz, C. H., Maia, J. C. C., Tenan, M. N., Braz-Padrao, G. R., MATtOON, J. R. \& PANEK, A. D. (1983). Regulation of yeast trehalase by a monocyclic, cyclic AMP-dependent phosphorylation-dephosphorylation cascade system. Journal of Bacteriology 153, 644-651.

VAN DER PlaAT, J. B. (1974). Cyclic 3',5'-adenosine monophosphate stimulates trehalose degradation in bakers' yeast. Biochemical and Biophysical Research Communications 56, 580-587.

Postma, E., Scheffers, W. A. \& Van Dijken, J. P. (1988). Adaption of the kinetics of glucose transport to environmental conditions in the yeast Candida utilis CBS 621 : a continuous culture study. Journal of General Microbiology 134, 1109-1116.

Postma, E., Verduyn, C., Scheffers, W. A. \& van Dijken, J. P. $(1989 a)$. Enzymic analysis of the Crabtree effect in glucose-limited chemostat cultures of Saccharomyces cerevisiae. Applied and Environmental Microbiology 55, 468-477.

Postma, E., Scheffers, W. A. \& van DiJken, J. P. (1989 b). Kinetics of growth and glucose transport in glucose-limited chemostat cuitures of Saccharomyces cerevisiae CBS 8066. Yeast 5, 159-165.

Reibstein, D., Den Hollander, J. A., Pilkis, S. J. \& Shulman, R. G. (1986). Studies on the regulation of yeast phosphofructo-1-kinase: its role in aerobic and anaerobic glycolysis. Biochemistry 25, 219-227.

RIEGER, M., KAPPELI, O. \& FieCHTER, A. (1983). The role of limited respiration in the incomplete oxidation of glucose by Saccharomyces cerevisiae. Journal of General Microbiology 129, 653-661.

Rittenhouse, J., Moberly, L. \& Marcus, F. (1987). Phosphorylation in vivo of yeast fructose-1,6-biphosphatase at the cAMP-dependent site. Journal of Biological Chemistry 26, 10114-10119.

SchaAfF, I., Heinisch, J. \& ZimmermanN, F. K. (1989). Overproduction of glycolytic enzymes in yeast. Yeast 5, 285-290.

Schmitt, H. D., Ciriacy, M. \& Zimmermann, F. K. (1983). The synthesis of yeast pyruvate decarboxylase is regulated by large variations in the messenger RNA level. Molecular and General Genetics 192, 247-252.

Sierkstra, L. N., Verbakel, J. M. A. \& Verrips, C. T. (1991). Optimisation of a host/vector system for heterologous gene expression by Hansenula polymorpha. Current Genetics 19, 81-87.

Smith, M. E., Dickinson, J. R. \& WheALs, A. E. (1990). Intracellular and extracellular levels of cAMP during the cell cycle of $S$. cerevisiae. Yeast 6, 53-60.

Toda, T., Cameron, S., Sass, P., Zoller, M., Scott, J. D., McMullen, B., Hurwitz, M., Krebs, E. G. \& Wigler, M. (1987). Cloning and characterization of $B C Y 1$, a locus encoding a regulatory subunit of the cAMP dependent protein kinase in Saccharomyces cerevisiae. Molecular and Cellular Biology 7, 1371-1377.

Uno, I., Matsumoto, K., Adachi, K. \& Ishikawa, T. (1983). Genetic and biochemical evidence that trehalase is a substrate of cAMP. dependent protein kinase in yeast. Journal of Biological Chemistry 258, 10867-10872.

VAN URK, H. (1990). Transient Responses of Yeasts to Glucose Excess. PhD thesis. Technical University, Delft, The Netherlands. 